\title{
Safe Colorectal Surgery in the COVID-19 Era - A Singapore Experience
}

\author{
Winson Jianhong Tan, Fung Joon Foo, Sharmini Su Sivarajah, Leonard Ho Ming Li, Frederick H Koh, \\ Min Hoe Chew \\ Department of General Surgery, Colorectal Service, Sengkang General Hospital, Singapore
}

\section{INTRODUCTION}

The COVID-19 pandemic crisis has had a staggering impact worldwide. Confirmed cases have increased exponentially and the number of infected individuals has since exceeded a million [1]. It is however important to realize that with limitations in testing, true infection rates may in fact be much higher [2]. In addition, presymptomatic transmission of infected individuals has been documented in China and lately confirmed in Singapore [35]. Our local data suggests that this can occur in $6.4 \%$ of patients but has been reported to be as high as $30 \%$ in other studies $[6,7]$.

Safe surgery has emerged as a topic of immense interest. As colorectal surgery accounts for a significant proportion of General Surgery workload [8], the COVID-19 pandemic thus has immense implications for many general and colorectal surgeons. In this current juncture of the pandemic with dangers of viral transmission, surgeons need to achieve a balance between surgical safety and judicious consumption of personal protective equipment (PPE). While deferment of nonurgent cases may be an initial strategy, this approach is impractical in the long run. The COVID-19 pandemic will likely have a protracted course and the resultant backlog of cases from indiscriminate deferment may overwhelm surgical capacity in the near future and compromise clinical care [9]. This is particular pertinent for common and timesensitive pathologies like colorectal cancer.

In Singapore, COVID-19 management has been one of prompt contact tracing and isolation to prevent transmission. Curtailment of travel as well as safe distancing measures at work and so-

Received: April 16, 2020 - Accepted: April 21, 2020

Correspondence to: Min Hoe Chew, MBBS, FRCS

Department of General Surgery, Sengkang General Hospital, 110 Sengkang

East Way, Singapore 544886, Singapore

Tel:+65-6930-5333, Fax:+65-68210610

E-mail: chew.min.hoe@singhealth.com.sg

ORCID: https://orcid.org/0000-0003-1628-3650

(C) 2020 The Korean Society of Coloproctology

This is an open-access article distributed under the terms of the Creative Commons Attribution NonCommercial License (https://creativecommons.org/licenses/by-nc/4.0) which permits unrestricted noncommercial use, distribution, and reproduction in any medium, provided the original work is properly cited. cial areas have all been imposed. Nonetheless, there have been a large number of imported cases with resultant community spread. In the authors' hospital, there have been 290 (latest figures as of 23/4/20) positive COVIDs to date.

While there has been a gradual reduction of elective workload over the last 2 months since the onset of the disease outbreak in Singapore, there continues to be a reasonable volume of cases performed. In this article, we share our colorectal unit's workflow (Fig. 1) and recommendations (Table 1) for safe practice in the COVID-19 era.

Workflow for patients undergoing elective colorectal procedures in the COVID-19 era:

Our workflow for evaluating patients scheduled for procedures (Endoscopy or Surgery) is illustrated in Fig. 1. Preprocedure risk stratification is done for all patients at 3 stages. At the initial anesthetist assessment 1-2 weeks preoperatively a chest X-ray or computed tomography thorax for cancer cases will be obtained to assess for consolidative changes in the lungs. Three days prior to the surgery date, our admission team will contact the patient to obtain a travel declaration and to inquire if there are new flu-like symptoms. On day of admission, this process is repeated with a formal declaration form signed by the patient.

Patients who have any travel history within 14 days, or has contact with any member of the public who is positive for COVID-19 or on home quarantine, or has new onset of flu-like symptoms will be advised on postponement of procedure. The procedure would be postponed by 2 to 4 weeks to allow infected patients who may be within the incubation period of COIVD-19 to declare themselves.

If there is clinical urgency, the procedure may proceed with precautions taken as per a presumed COVID-19 positive patient (Fig. 1). Clinical urgency refers to cases which necessitate intervention within 2 weeks. These include colorectal cancer cases with impending obstruction or with overt bleeding resulting in significant transfusion requirements. Postoperatively, such patients will undergo COVID-19 testing and will be nursed in isolation until their test results clear them from COVID-19 infection.

At the current moment, universal COVID-19 testing for all pa- 
tients undergoing surgery is not performed. We only perform testing for patients who meet the suspect case definition stipulated by the Ministry of Health, Singapore. As of 16 April 2020, the case definition is as follows:
(1) A person with clinical signs and symptoms suggestive of Community-Acquired Pneumonia or community-acquired severe respiratory infection with breathlessness.

(2) A person with an acute respiratory illness of any degree of

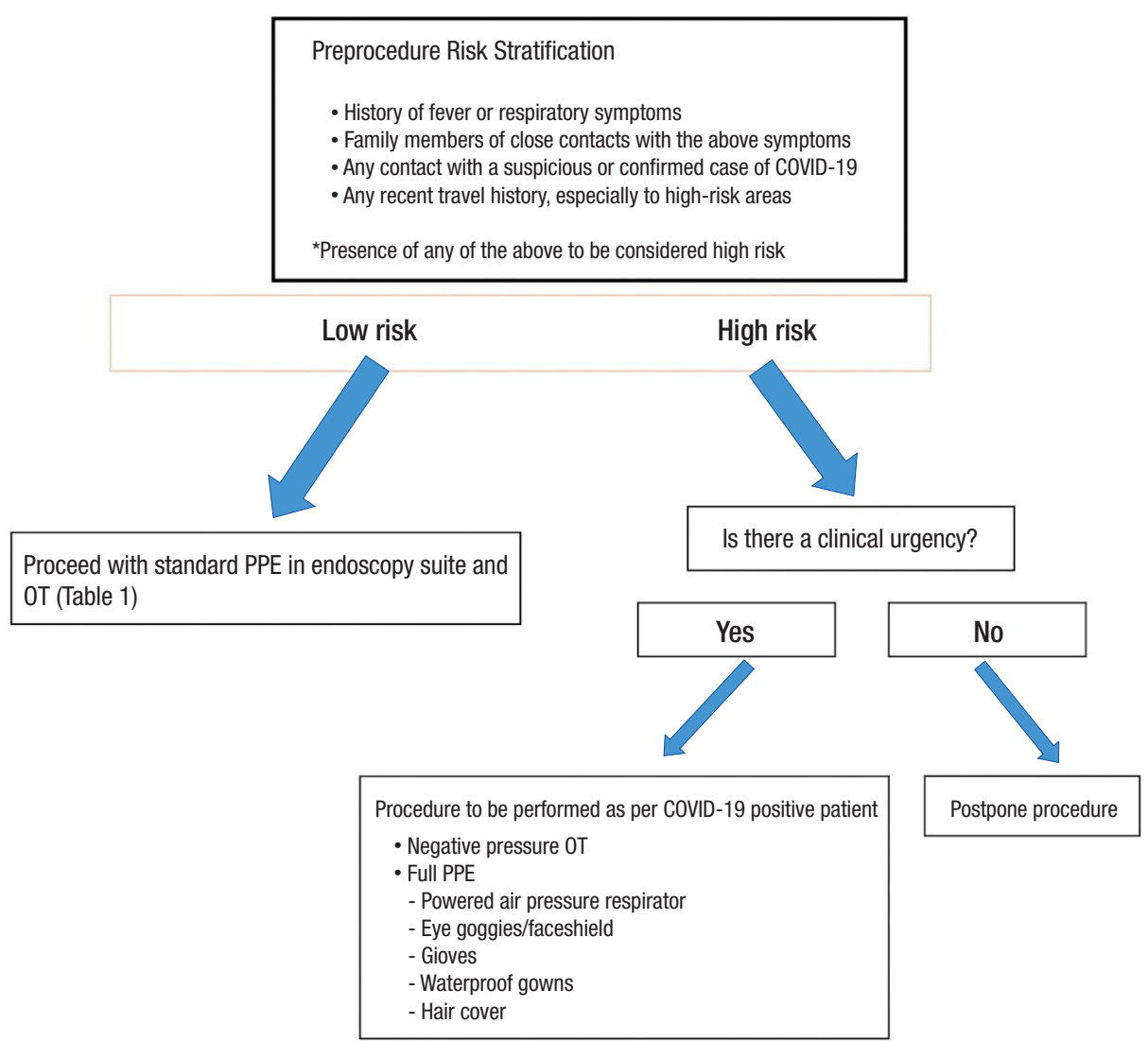

Fig. 1. Proposed workflow for patients undergoing Endoscopy or Surgery in the COVID-19 era. PPE, personal protective equipment; OT, operating theater.

Table 1. Proposed personal protective equipment (PPE) and safety measures for colorectal procedures

\begin{tabular}{lll}
\hline Procedure & PPE recommendations & \multicolumn{1}{c}{ Other safety measures } \\
\hline Endoscopy procedures & Face shields/eye goggles & Minimize use of energy during procedures \\
& N95 respirator masks & Avoid procedures like EMR/ESD which may require additional insufflation \\
& Gloves & \\
Waterproof gown & & \\
Open colorectal resections & Face shields/eye goggles & Electrocautery set to the lowest possible settings \\
& Hair cover & Minimize use of ultrasonic dissectors or advanced bipolar devices \\
& N95 respirator mask & Diathermy pencils with attached smoke evacuators encouraged \\
& Gloves & \\
Waterproof gown & Face shields/eye goggles & Minimize port incisions to prevent leakage \\
Laparoscopic colorectal resections & Consider use of smoke evacuation system \\
& Hair cover & Pneumoperitoneum to be safely evacuated using filtration system or suction device prior to \\
& N95 respirator mask & specimen extraction or port removal \\
& Waterproof gown & \\
\hline
\end{tabular}

EMR, endoscopic mucosal resection; ESD, endoscopic submucosal dissection. 
severity (e.g., symptoms of cough, sore throat, runny nose, anosmia), with or without fever, who, within 14 days before onset of illness had: (a) Travelled abroad (outside Singapore); (b) Close contact with a case of COVID-19 infection.

\section{PROCEDURAL CONSIDERATIONS}

\section{Endoscopy}

Endoscopy carries an increased risk of COVID-19 infection from droplets inhalation, conjunctival contact and fomite contamination. Upper gastrointestinal (GI) endoscopy is recognized to be a high risk aerosol-generating procedure (AGP) [10]. However, it is important to highlight that colonoscopy may also pose significant risks. The 2019-nCoV has been consistently isolated in stool samples and fecal oral transmission is recognized [11-13]. It remains unknown if gas insufflation during colonoscopy may be considered an AGP. In our unit, we adopt the same PPE measures for colonoscopy as for a gastroduodenoscopy. A summary of our PPE recommendations for endoscopy is summarized in Table 1.

\section{Colorectal surgery}

\section{Minimally invasive surgery}

There is scant evidence regarding the risks of virus transmission of minimally invasive surgery (MIS) or open surgery. However, data does indicate that laparoscopy can lead to aerosolization of blood borne viruses, although it remains unknown if this applies to COVID-19 [14, 15].

As such, while we still perform MIS procedures, surgeons are recommended to adopt the necessary PPE precautions. (Table 1) Filtration systems applied to trocars for smoke evacuation and safe evacuation of pneumoperitoneum may be considered but the efficacy of such measures remains unknown.

The risks of transanal MIS procedures (taTME - transanal total mesorectal excision, TAMIS-transanal minimally invasive sur- gery) remains unknown in the COVID-19 era. However, the 2019-nCoV has been demonstrated in stool samples, and with the strong potential risks while evacuating air per-anally, these procedures should be performed with extreme caution in the current climate $[11-13,16]$.

\section{Open surgery}

Smoke from electrocautery during open surgery can harbor virus particles [17]. Unlike MIS, the exposure of the surgeon to smoke inhalation is likely higher in open surgery which raises the possibility of COVID-19 transmission. Measures to mitigate risks of transmission should thus be adopted. These, together with our proposed PPE for open surgery, are summarized in Table 1.

\section{Operating room management during surgery}

Most operating room (ORs) have an average of 15-40 air exchanges per hour. To ensure clean air in the OR, 14-18 minutes is thus required [18]. In our institution, an intubation-extubation protocol has been in practice since the COVID-19 outbreak. In this protocol, a 5-minute pause has been mandated during intubation and extubation, with only the anesthetists and assistant in OR wearing full PPE. This ensures at least 2 gas exchanges of the $\mathrm{OR}$, and enhances safety in the scenario that surgeons are operating on an undiagnosed COVID-19 case. To address the concerns of laparoscopy, an additional 15 minutes has been factored in, which commences on evacuation of the pneumoperitoneum. This allows a complete 20 minutes of air exchange on completion of surgery and extubation [19].

For COVID-19 cases, surgery is performed in a dedicated negative pressure OR. In the negative pressure OR, the induction and scrub room is maintained at a pressure of -2.5 Pascals relative to the exterior to prevent dissemination of aerosolized virus particles. Fig. 2 illustrates the setup of our negative pressure OR.

The COVID-19 pandemic is likely to run a protracted course

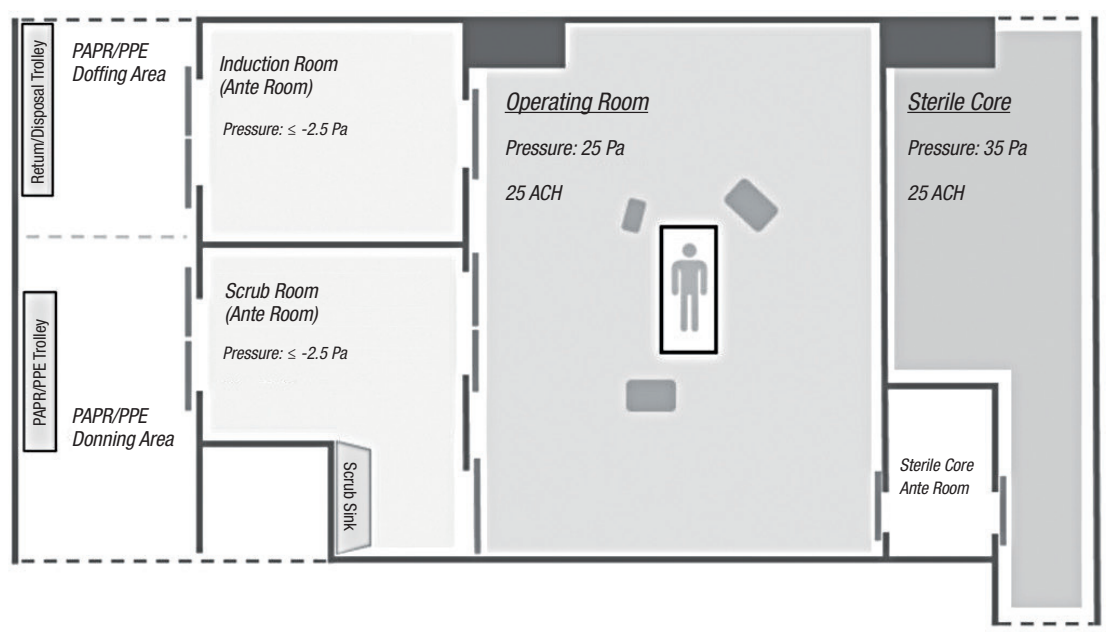

Fig. 2. Negative pressure OR setup. PAPR, positive air pressure respiratory; PPE, personal protective equipment; $\mathrm{ACH}$, air exchanges per hour. 
Table 2. Recommendations of various professional societies on procedures during the COVID-19 pandemic

\begin{tabular}{|c|c|c|c|c|c|}
\hline $\begin{array}{l}\text { Recommendations } \\
\text { regarding Surgical } \\
\text { Response to COVID-19 }\end{array}$ & $\begin{array}{l}\text { SAGES and EAES } \\
(29 \text { Mar 2020) }\end{array}$ & $\begin{array}{c}\text { Gastroenterology } \\
\text { Professional Society Guidance } \\
\text { (ASGE, AGA, ACG, AASLD) } \\
\text { (31 Mar 2020) }\end{array}$ & $\begin{array}{l}\text { European Society of } \\
\text { Gastrointestinal } \\
\text { Endoscopy } \\
(18 \text { Mar 2020) }\end{array}$ & $\begin{array}{l}\text { Intercollegiate General } \\
\text { Surgery Guidance } \\
\text { (27 Mar 2020) }\end{array}$ & $\begin{array}{l}\text { American College } \\
\text { of Surgeons } \\
(24 \text { Mar 2020) }\end{array}$ \\
\hline Endoscopy & $\begin{array}{l}\text { All elective cases to be } \\
\text { postponed }\end{array}$ & $\begin{array}{l}\text { All elective procedures to be delayed } \\
\text { Patients with time-sensitive diagnosis } \\
\text { to proceed with evaluation }\end{array}$ & $\begin{array}{l}\text { Strongly consider postponing } \\
\text { elective, nonurgent } \\
\text { procedures }\end{array}$ & $\begin{array}{l}\text { Only emergency procedures } \\
\text { to be performed } \\
\text { No diagnostic work to be } \\
\text { done }\end{array}$ & NA \\
\hline Surgery & $\begin{array}{l}\text { All elective cases to be } \\
\text { postponed } \\
\text { Surgical care limited to } \\
\text { those whose needs } \\
\text { are imminently life } \\
\text { threatening }\end{array}$ & NA & & $\begin{array}{l}\text { Largely confined to } \\
\text { emergency surgery } \\
\text { Stoma formation to be } \\
\text { considered rather than } \\
\text { anastomosis }\end{array}$ & $\begin{array}{l}\text { Tiered approach for } \\
\text { cancer cases }\end{array}$ \\
\hline
\end{tabular}

SAGES, society of american gastrointestinal and endoscopic surgeons; EAES, european association of endoscopic surgery; ASGE, american society for gastrointestinal endoscopy; AGA, american gastroenterological association; ACG, american college of gastroenterology; AASLD, american association for the study of liver diseases; NA, not applicable.

and has immense implications on colorectal practice. Various academic societies have provided guidance for clinical practice and these are summarized in Table 2 [10,20-23]. While the measures we have in place have allowed safe colorectal surgery, there are several modifications that may have to be considered in view of increasing community transmission and recognition of presymptomatic transmission. One suggestion is that routine bowel preparation may be considered to reduce fecal load during bowel surgery. Secondly, the appropriate PPE in this era needs to be reviewed and perhaps all OR staff should be in N95 respirators for all colorectal procedures until there is more evidence regarding transmission risk during surgery. The difficulty, however, is having the availability of resources and its pragmatic allocation. Thirdly, universal preoperative COVID-19 testing may seem to be intuitively better and replace clinical stratification but the issues of false negatives and limited COVID-19 testing capacity may hamper widespread implementation. We urge the colorectal fraternity to share their workflows and protocols to ensure safe practice among our community amidst this uncertain era.

\section{REFERENCES}

1. John Hopkins Coronavirus Resource Centre [Internet]. Baltimore (MD): Johns Hopkins University \& Medicine; c2020 [cited 2020 Apr 8]. Available from: https://coronavirus.jhu.edu/map.html.

2. Li R, Pei S, Chen B, Song Y, Zhang T, Yang W, et al. Substantial undocumented infection facilitates the rapid dissemination of novel coronavirus (SARS-CoV2). Science 2020 Mar 16 [Epub]. pii: eabb3221. https://doi.org/10.1126/science.abb3221.

3. Qian G, Yang N, Ma AHY, Wang L, Li G, Chen X, et al. A COVID-19 Transmission within a family cluster by presymptomatic infectors in China. Clin Infect Dis 2020 Mar 23 [Epub]. pii: ciaa316. https://doi.org/10.1093/cid/ciaa316.

4. Tong ZD, Tang A, Li KF, Li P, Wang HL, Yi JP, et al. Potential Pre- symptomatic Transmission of SARS-CoV-2, Zhejiang Province, China, 2020. Emerg Infect Dis 2020;26:1052-4.

5. Wei WE, Li Z, Chiew CJ, Yong SE, Toh MP, Lee VJ. Presymptomatic transmission of SARS-CoV-2 - Singapore, January 23-March 16, 2020. MMWR Morb Mortal Wkly Rep 2020;69:411-5.

6. Kimball A, Hatfield KM, Arons M, James A, Taylor J, Spicer K, et al. Asymptomatic and Presymptomatic SARS-CoV-2 Infections in Residents of a Long-Term Care Skilled Nursing Facility - King County, Washington, March 2020. MMWR Morb Mortal Wkly Rep 2020;69:377-81.

7. Nishiura H, Kobayashi T, Suzuki A, Jung SM, Hayashi K, Kinoshita R, et al. Estimation of the asymptomatic ratio of novel coronavirus infections (COVID-19). Int J Infect Dis $2020 \mathrm{Mar} 13$ [Epub]. pii: S1201-9712(20)30139-9. https://doi.org/10.1016/j. ijid.2020.03.020.

8. Goligher J. Colorectal surgery as a specialty. J R Soc Med 1996; 89:601-3.

9. Lisi G, Campanelli M, Spoletini D, Carlini M. The possible impact of COVID-19 on colorectal surgery in Italy. Colorectal Dis 2020 Mar 30 [Epub]. https://doi.org/10.1111/codi.15054.

10. Gralnek IM, Hassan C, Beilenhoff U, Antonelli G, Ebigbo A, Pellisè $\mathrm{M}$, et al. ESGE and ESGENA Position Statement on gastrointestinal endoscopy and the COVID-19 pandemic. Endoscopy 2020 Apr 17 [Epub]. https://doi.org/10.1055/a-1155-6229.

11. Wu Z, McGoogan JM. Characteristics of and Important Lessons From the Coronavirus Disease 2019 (COVID-19) Outbreak in China: Summary of a Report of 72314 Cases From the Chinese Center for Disease Control and Prevention. JAMA 2020 Feb 24 [Epub]. https://doi.org/10.1001/jama.2020.2648.

12. Xiao F, Tang M, Zheng X, Liu Y, Li X, Shan H. Evidence for Gastrointestinal Infection of SARS-CoV-2. Gastroenterology $2020 \mathrm{Mar}$ 3 [Epub]. pii: S0016-5085(20)30282-1. https://doi.org/10.1053/ j.gastro.2020.02.055.

13. Yeo C, Kaushal S, Yeo D. Enteric involvement of coronaviruses: is 
faecal-oral transmission of SARS-CoV-2 possible? Lancet Gastroenterol Hepatol 2020;5:335-7.

14. Alp E, Bijl D, Bleichrodt RP, Hansson B, Voss A. Surgical smoke and infection control. J Hosp Infect 2006;62:1-5.

15. Choi SH, Kwon TG, Chung SK, Kim TH. Surgical smoke may be a biohazard to surgeons performing laparoscopic surgery. Surg Endosc 2014;28:2374-80.

16. Gu J, Han B, Wang J. COVID-19: Gastrointestinal Manifestations and Potential Fecal-Oral Transmission. Gastroenterology $2020 \mathrm{Mar}$ 3 [Epub]. pii: S0016-5085(20)30281-X. https://doi.org/10.1053/ j.gastro.2020.02.054.

17. Liu Y, Song Y, Hu X, Yan L, Zhu X. Awareness of surgical smoke hazards and enhancement of surgical smoke prevention among the gynecologists. J Cancer 2019;10:2788-99.

18. Centers for Disease Control and Prevention. Infection Control. Guidelines \& Guidance Library [Internet]. Atlanta (GA): Centers for Disease Control and Prevention; [cited 2020 Apr 8]. Available from: https://www.cdc.gov/infectioncontrol/guidelines/index. html.

19. Chew MH, Koh FH, Ng KH. A call to arms: a perspective of safe general surgery in Singapore during the COVID-19 pandemic. Singapore Med J 2020 Apr 3 [Epub]. https://doi.org/10.11622/ smedj.2020049.

20. SAGES and EAES Recommendations Regarding Surgical Response to Covid-19 Crisis [Internet]. Los Angeles (CA): SAGES; [cited 2020 Apr 8]. Available from: https://www.sages.org/recommendations-surgical-response-covid-19/.

21. COVID-19 Guidelines for Triage of Colorectal Cancer Patients [Internet]. Chicago (IL): American College of Surgeons; c19962020 [cited 2020 Apr 8]. Available from: https://www.facs.org/covid-19/clinical-guidance/elective-case/colorectal-cancer.

22. Gastroenterology Professional Society Guidance on endoscopic procedures during the COVID-19 pandemic [Internet]. Downers Grove (IL): American Society for Gastrointestinal Endoscopy; [cited 2020 Apr 8]. Available from: https://www.asge.org/home/ advanced-education-training/covid-19-asge-updates-for-members/gastroenterology-professional-society-guidance-on-endoscopic-procedures-during-the-covid-19-pandemic.

23. Intercollegiate General Surgery Guidance on COVID-19 update [Internet]. Edinburgh (UK): The Royal College of Surgeons of Edinburgh; c2020 [cited 2020 Apr 8]. Available from: https:// www.rcsed.ac.uk/news-public-affairs/news/2020/march/intercollegiate-general-surgery-guidance-on-covid-19-update. 